\title{
CLIMATE CHANGE INDUCED FLOOD AND LANDSLIDES AND FARMER'S ADAPATATION PRACTICES IN PADDY PRODUCTION: EVIDENCE OF RURAL HILLY NEPAL
}

\author{
Raghu Bir Bista, $\mathrm{PhD}^{1}$ and Ranjan Kumar Dahal, $\mathrm{PhD}^{2}$ \\ ${ }^{1}$ Associate Professor, Department of Economics and ${ }^{2}$ Associate Professor, Department of Geology, \\ Tribhuvan University, Nepal \\ Corresponding author e-mail: bistanepal@gmail.com
}

Abstract

Climate change is a buzzword in the world. Scientist has approved it as global warming with its projection of undesired and unpredicted frequent extreme events and their vulnerabilities not only at present but also at future. There is an assumption of occurrence of adaptive capacity and behavior of farmers in agriculture production activity at some extent to neutralize climate change vulnerabilities of flood and landslides on paddy production. This paper empirically examines the effects of climate change in paddy production and farmer's adaptive behaviors to neutralize such climatic shocks and events in paddy production by employing Cobb Douglas (CD) production function based econometric model. The study employed primary data collected through 642 household surveys. The study finds that climatic shocks and events have huge loss $(60 \%)$ in paddy production and revenue income in such plot where farmers have not indigenous knowledge and practices. Climatic flood made 2.62 Rs (0.0262 USD) per kg revenue loss and landslide made 3.97 Rs (0.0397 USD) per $\mathrm{kg}$ revenue loss. But both small and larger farmers who have adaptive capacity and behavior with their indigenous knowledge have less loss in paddy production and revenue income, although they have heterogeneity in their socio-economic characteristics (income, asset holding, literacy, experience, land holding and age). The farmers have indigenous knowledge and experiences including bamboo wall construction to control flood and landslides and seed change to resist climatic shocks and events. In hilly region, the farmers have limited wall construction and removing sedimentation measures because of their poverty, illiteracy and remote locations. The study finds their higher effective level to minimize vulnerabilities to paddy production and revenue per farm plot, although these adaptive behaviors are cost effective and local entity. Comparatively, bamboo wall construction is more effective measure in the paddy production than others are (seed switch) to minimize the flooding materials from the flood and the landslides. Thus, low cost indigenous adaption behavior of farmers is effective measure to climate change and climate change induced disasters and events vulnerability in paddy production. 


\section{Introduction}

Climate change is scientifically well-established issue in developing countries. It occurred but was just experienced in the grass root level. In 2001, IPCC (2001) recognized scientifically it. Further Stern (2006) incorporated it with the projection of $2^{0} \mathrm{C}-3^{0} \mathrm{C}$ temperature rising in next 50 years. Likely, Eliasch (2008) verified the projection of Stern (2006) by explaining that more than half of the population has experienced the variation on the global temperature in the world by $0.7^{\circ} \mathrm{C}$ over the past decades. Except temperature raising and temperature rising induced changing climate variables occurred. Stern (2006) mentioned different features of climate change such as melting glaciers, disturbance of monsoon cycle, flooding, drought and cyclones having a potential huge damage cost of GDP loss of developing countries more than developed countries, if climate change is not stabilized through mitigation. For example: climate displacement in Asia is another economic cost in which its severity was nearly 7 million people in India and 15 million people in Bangladesh (Nicholl, Leatherman, K.C. and Volonte, 1995). Further, Stern (2006) projected that a large population of developing countries particularly African and Asian countries will suffer from malnutrition, food deficit, water scarcity, deaths and diseases in future (Stern, 2006). Thus, the growth of climate change induced vulnerability has become a critical issue in developing countries, particularly in Asia.

Different studies have indicated climate change in Nepal. CBS (2011) found the variability of mean temperature from $0.4^{\circ} \mathrm{C}$ to $0.6^{\circ} \mathrm{C}$ and the variability of mean rainfall. Mool, Bajarcharya and Joshi(2001a) have mentioned change in temperature and rainfall more than earlier (1970). Different studies have shown climate change induced disasters (landslide, drought, cyclones and flooding). Different forms of climate change have occurred as its frequency of natural calamities (landslide, drought, cyclones, glacial outburst and flooding), variability of rainfall and average temperature rising all over the country than earlier (1970). In such disasters, there were Glacial lake outburst floods (GLOF), namely Dudh Khosi GLOF 1985, Tamakhosi GLOF 1991 and Dudh Khosi GLOF, 1998 (Mool, Bajaracharya and Joshi, 2001a). Such flood destroyed the Namche hydropower plant and a number of bridges, along with the loss of valuable life (Chalise and Khanal, 2002). Another was floods with the higher intensity of rainfall over 48 hours, namely Nakhu Khola in 1981, Bagmati and Narayani in 1993, Andhi Khola in 1998 and Bagmati in 2002 (Chalise and Khanal, 2002). Almost such floods were disastrous. The 1991 flood not only destroyed nearly all the agricultural land in Le Le VDC, more than 48 houses and seven water turbines and but also killed twentyseven people. The 1993 flood disaster fully and partially affected nearly 28,000 families in the middle mountains and 42,000 families in the lowlands (Chalise and Khanal, 2002). About 1000 people were killed during that climatic event. The 1996 Larcha debris flow washed away physical infrastructure including roads, bridges and transmission lines, along with 18 houses. Floods of a smaller scale of less disastrous, but still considerable, impact occur annually to a number of locations (Chalise and Khanal, 2002). Thus, Nepal has its mean loss was of 2000 million Nepali Rupees per annum including dead, missing, damage, loss of asset, death of livestock (CBS, 2011). Therefore, climate change and climate change induced disasters and their huge damage cost to households in Nepal are key issues. Furthermore, it is complicated in case of the poor and marginal household including small farmers and landless farmers.

Studies have shown uneven climate change distribution all over Nepal but its higher intensity is in the western Nepal. Malla (2008) noted average of $1.8^{0} \mathrm{C}$ in temperature rise from 1975 to 2006 but Karn (2014) mentioned $1^{0} \mathrm{c}$ rise of temperature. Similarly, Acharya (2012) found rising temperature with $2^{0} \mathrm{C}$ average per annum. It is relatively three times higher than lower temperature within the country and significantly higher in the comparison of global trend of temperature variation. Average temperature growth within the last 36 years (1975-2010) in western Nepal also is $1.2^{\circ} \mathrm{C}$, which is two times high of the global average. Further, Malla (2008) explained problem of frequent drought, severe floods and landslide. Dahal, Hasegawa, Nonomura, Yamanaka, Dhakal, and Paudyal (2008) established the proper relationship between rainfall and landslide. Karki, Shrestha and Winiger (2011) linked with flood and its hazard.

Studies have found negative effects of climate change on households and their economic activities. Bhandari (2013) noted the adverse effect of changing climate variables (high temperature and low rainfall) in 
Dedeldhura, Western Nepal. Karki, Shrestha and Winiger (2011) found its socio-economic effects on household in the country. Pant (2011) and Acharya and Bhatta (2013) have explained the negative impact of climate change in agriculture. Malla (2008) and Karn (2014) found its negative impact on paddy yield. Pant (2012) found negative effect on the national self-sufficiency of food grains. Thus, climate change in the western Nepal has become a critical issue.

It is urgent to respond climate change. Different studies (IPCC, 2001; Stern, 2006 and Elisch, 2008) explain two measures: mitigation and adaptation. Most studies (Nicholls, Leatherman, K.C and Volonte, 1995; IPCC, 2001; Fussel and Kelin, 2003; Adger, 2006, Stern, 2006; Elisch, 2008 and UNFCCC, 2008) prefer adaptation option to maintain business as usual at household with assumption of the occurrence of adaptation capacity into indigenous knowledge and technology (Stern, 2006). In addition, households have adaptation behaviors to minimize climate change vulnerability at either individual level or community level (Fussel, 2007). Most individual migrate to the safe location from their own location to save life and asset (Adger, 2006). In agriculture, households change crop seeds and change fertilizer. However, the community prefers a long-term adaptation behavior as the intervention in irrigation development, forest conservation and technology adaptation (Nicholls, Leatherman, K.C and Volonte. 1995). Therefore, households have adaptation capacity and behaviors.

Sot khola watershed and its catchment areas (Figure 2) are relevant to be analyzed and empirically examined on the relationship between climate change and adaptation behavior. Its reason is notable heavy erratic rainfall in upper stream and its sever multi hazard in these watershed and its catchment areas in 2014 (DDC, 2015) and its induced aggressive flood and disastrous landslides had eroded heavily watershed morphological structure by loading and disposing sedimentation and cutting banks of agricultural lands in Gadhi, Lekhagaon and Kunathari VDCs. Further, there was structural damage: houses, bridges, canals, pipelines and roads (Field Survey, 2015). Out of total household production, there were 66 percent losses in crop and 34 percent livestock losses. Its loss value was about Rs. 18,464,427 (18.4 million rupees). Further, there was risk of human life from water borne diseases and food insecurity. About 69 percent households were vulnerable. Such multi hazard had huge cost of more than 30 million Rupees (DDC, 2015). In this context, this study measures whether climate change vulnerability has higher intensity and huge cost in paddy production, whether farmer across different income level and regions have adaptation capacity, whether farmer's adaptation behaviors are effective to minimize climate change vulnerability. Its outcomes may be valuable information and data to the policy makers of Nepal to generate the data of climate change vulnerability for specific noticeable mapping for initiating adaptation and mitigation policy and program in paddy production.

\section{Objectives and Method}

The overall objective of this study is to measure climate change and its vulnerability at farmer household level in Nepal. The study has specific objectives as follows: to understand climate change vulnerability and its effects in agriculture, to analyze farmer's adaptation behavior undertaken in agriculture in the study area and to identify issues related to farmer's adaptation in agriculture

Let us assume farmer has adaptation capacity and behavior in agriculture activities against the variation of temperature and rainfall and their induced disasters (flood and landslides) in the fact of that agriculture is main source of household livelihood, paddy production is main cereal production of farmers and almost farmers are illiterate and conservative. In order to capture farmer's climate vulnerability, adaptation capacity and behavior in paddy production, Cobb-Douglas (CD) production function was employed. Its functional form (Equation-16) can be as follows.

$$
\operatorname{Ln} R=\beta_{0}+\beta_{1} \operatorname{Ln} P_{c}+\beta_{2} \operatorname{Ln} P_{L}+\beta_{3} \operatorname{Ln} X_{L B}+\beta_{4} \operatorname{Ln} X_{F T}+\beta_{5} \operatorname{Ln}(R F G)+\beta_{6} D_{m i}+\beta_{7} D_{m j}+\varepsilon
$$

Where,

$\mathrm{R}$ =gross revenue per hectare (Rs),

$\mathrm{P}_{\mathrm{c}}=$ price of paddy $(\mathrm{Rs})$, 
$\mathrm{P}_{\mathrm{l}}=$ price of livestock (cow, buffalo, goat and others) (Rs),

$\mathrm{X}_{\mathrm{lb}}=$ total labor $(\mathrm{Rs})$,

$\mathrm{X}_{\mathrm{Ft}}=$ fertilizer $(\mathrm{kg})$,

$\mathrm{RFG}=$ precipitation,

$\mathrm{D}_{\text {mi }}=$ adaptive shock1,

$\mathrm{D}_{\mathrm{mj}}=$ adaptive shock 2 ,

$\varepsilon=$ error term

Farmer's adaptation behavior household vulnerability in terms of income lost in log form ( $\left.\mathrm{Y}_{\text {paddyre }}\right)$ is dependent variable. Similarly, number of labor $\left(X_{1 \mathrm{nl}}\right)$, land $\left(\mathrm{X}_{2 \mathrm{Laag}}\right)$, fertilizer $\left(\mathrm{X}_{3 \mathrm{fe}}\right)$, $\operatorname{Seed}\left(\mathrm{X}_{4 \mathrm{se}}\right) \mathrm{D}_{\text {0clsho }}($ climate shock), $\mathrm{D}_{\text {ladsho }}\left(\right.$ Adaptation Shock), $\mathrm{D}_{2 \mathrm{Ga}}(\mathrm{Gadhi}), \mathrm{D}_{3 \text { lekh }}$ (Lekhagaon) and $\mathrm{D}_{8 \mathrm{kuna}}$ (Kunathari) are independent variables where $\mathrm{D}_{\text {0clsho }}\left(\right.$ climate shock), $\mathrm{D}_{\text {ladsho }}$ (Adaptation Shock), $\mathrm{D}_{2 \mathrm{Ga}}(\mathrm{Gadhi}), \mathrm{D}_{3 \text { lekh }}$ (Lekhagaon) and $\mathrm{D}_{8 \mathrm{kuna}}$ (Kunathari) are dummies. Standard deviations of these variables from mean are no so far significant. The mean of these variables represents properly household data collected from primary sources. There are eight estimators: $\beta, \beta_{1}, \beta_{2}, \beta_{3}, \beta_{4}, \beta_{5}, \beta_{6}, \beta_{7}$, and $\beta_{8}$. C-D Production Function (Equation-17) is as follows.

$\ln \mathrm{Y}_{\mathrm{paddyre}}=\beta+\beta_{1} \ln \mathrm{X}_{1 \mathrm{nl}}+\beta_{2} \ln \mathrm{X}_{2 \mathrm{Laag}}+\beta_{3} \ln \mathrm{X}_{3 \mathrm{fer}}+\beta_{4} \ln \mathrm{X}_{4 \mathrm{se}}+\beta_{5} \mathrm{D}_{0 \mathrm{clsho}}+\beta_{6} \mathrm{D}_{1 \mathrm{adsho}}+\beta_{7} \mathrm{D}_{2 \mathrm{Ga}}+\beta_{8} \mathrm{D}_{3 \text { lekh }}+\varepsilon$

\section{Data Sets and Sources}

Data sets on socio economic characteristics of farmers, climate change vulnerability and adaptation capacity and behavior of farmers for this study were primary. The study employed household survey to collect the primary data in the watershed catchment areas of Sot Khola (Gadhi VDC, Lekhagaon VDC and Kunathari VDC) and used secondary information to supplement the primary data. The selection of the sample catchment VDCs were purposive. Its household sample size was 642 (19.3 percent). Its sampling method was random to select the sample households from nine ward unit clusters, out of total population (3310) (CBS, 2011) .

Structural questionnaire was a tool of household survey. The study conducted the survey from September 2 to October $15^{\text {th }}, 2015$ in the catchment households after its pretest. Its major concern was to generate socio economic information, agriculture, paddy production, climate vulnerability and farmer's adaptive capacity and behavior in the study area.

This chapter is organized into the following sections: Section 7.1: Introduction, Section 72: Agricultural Status and Characteristics, Section 7.3: Review of Policy Intervention 7.4. Risks in Agriculture Sector 7.5 Climatic Change and Climate change induced hazards and Vulnerability, 7.6. Adaptation Options Practiced Activity and Behavior in Agriculture Sector, 7.7. Household's Adaptation Activity and Behavior in Agriculture and 7.8 Analysis of Community and Household Adaptation to climate change and climate change induced hazards. 
Figure 1: Study Area : Surkhet District

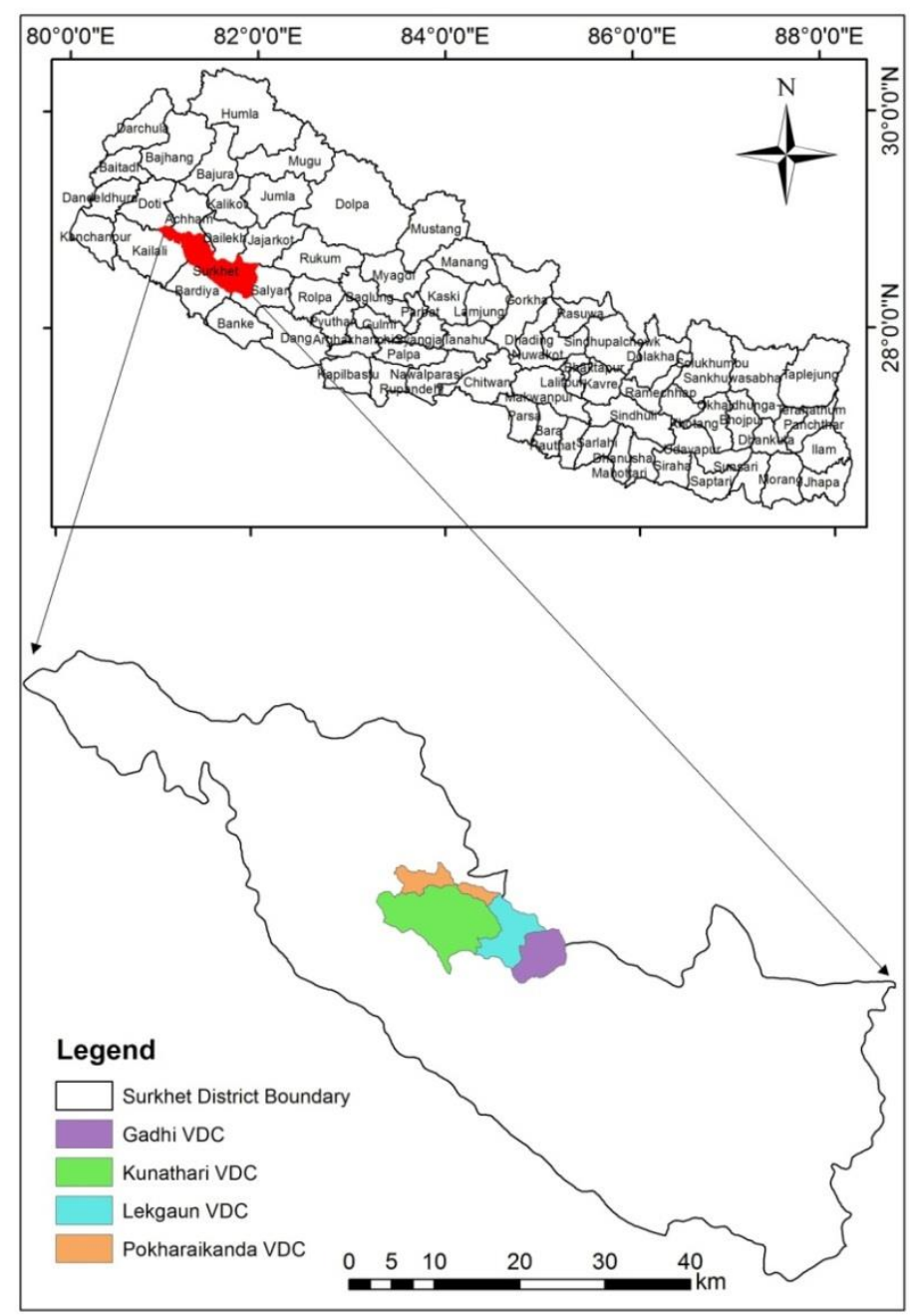

\section{Study Area: Sot khola - watershed and its catchment areas}

In the western Nepal, this watershed and its catchment areas, out of total watersheds of Surkhet district was the study area (Figure 1). Its district location is 600 kilometers far west from Kathmandu valley (Figure 1). It lies in Bheri zone of Mid-Western Development region (DDC, 2015). Its size is approximately $2,451 \mathrm{~km}^{2}$ lying between latitude of $28^{\circ} 20^{\prime} \mathrm{N}$ to $28^{\circ} 58^{\prime} \mathrm{N}$ and longitude $80^{\circ} 59^{\prime} \mathrm{E}$ to $82^{\circ} 02^{\prime} \mathrm{E}$. Ecologically, the district varies across the different altitude from 198 meter to 2367 meter from sea level. Climate zones are four in Surkhet (DDC, 2015) (Table 1). There are hot and dry tropic to cool temperate. Mean temperature ranges from $4.5^{\circ} \mathrm{C} \mathrm{min}$. to $37.1^{\circ} \mathrm{C}$ max. Mean rainfall is $1603 \mathrm{~mm}$. In monsoon, rainfall is recorded at $1312 \mathrm{~mm}$.

Population size in Surkhet is about 350 thousand, in which sex ratio is 0.92 with 52 percent female (CBS, 2011) and their poverty level is 30 percent. It is higher than national average. In HPI, the district lies at 49th with 36.4 values. District per capita income is 563 USD compared to 718 USD of national average (DDC, 2015). HDI 2014 ranks the district at $34^{\text {th }}$ with 0.476 values. Their heterogeneous caste composition is of Cheetri, Brahmin, Janajati, Dalit, Thakuri and Other minority castes (Tharu, Badi, Newar \& Muslim). heetri dominates with 32

percent to all. Dalit (25 percent) and other minority castes (20 percent) follow it.

Geological studies indicate weak landscape of the district. Rugged hilly land with 57 percent dominates to the plain land with 42 percent (DDC, 2015). The rugged hilly land is comprised of 43 percent Mahabharat Range and 15 percent Siwalik.

District profile (2015) shows agrarian economy in which most households have agrarian livelihood, although only 25 percent plain land is utilized for sistence agriculture. Agricultural District office (2018) mentions divergent crops: major crops (paddy, wheat and maize) and non-traditional crops (vegetables, citrus fruits, potato, mustard and lentils). Still, cereal crops traditionally dominate in monsoon rain fed sistence agriculture. Thus, their lower productivity leads to critical food insecurity.

Surkhet is rich in natural resources: forest (71.4\%) and agriculture plus settlement (26.4\%) and water resources including Bheri and Karnali as major rivers and Chigadh Khola, Jhupra Khola, Simta Khola, Jum Khola, Rate Khola, Khakhre Khola, Gam Khola, Guthu Khola, Soth Khola, Goche Khola, Neware Khola, Itram Khola, Khorke Khola, Girighat Khola, Bidhyapur Khola, etc as minor rivers (DDC, 2015). 
Sotkhola watershed (Figure 2) is one of watershed as a tributary of Bheri River (Figure 2). It begins from Chandane, Gadhi VDC and ends to Rakseni, Kunathari VDC (Figure 2). Its length is about $30 \mathrm{~km}$ (DDC, 2015). This watershed has mainly three catchment areas: Gadhi VDC (Upper stream), Lekhagaon VDC (middle stream) and Kunathari VDC (downstream) (DDC, 2015). a) Gadhi VDC lies at the altitude of 1200

Figure 2: Study Area: SotKhola watershed Catchment Areas

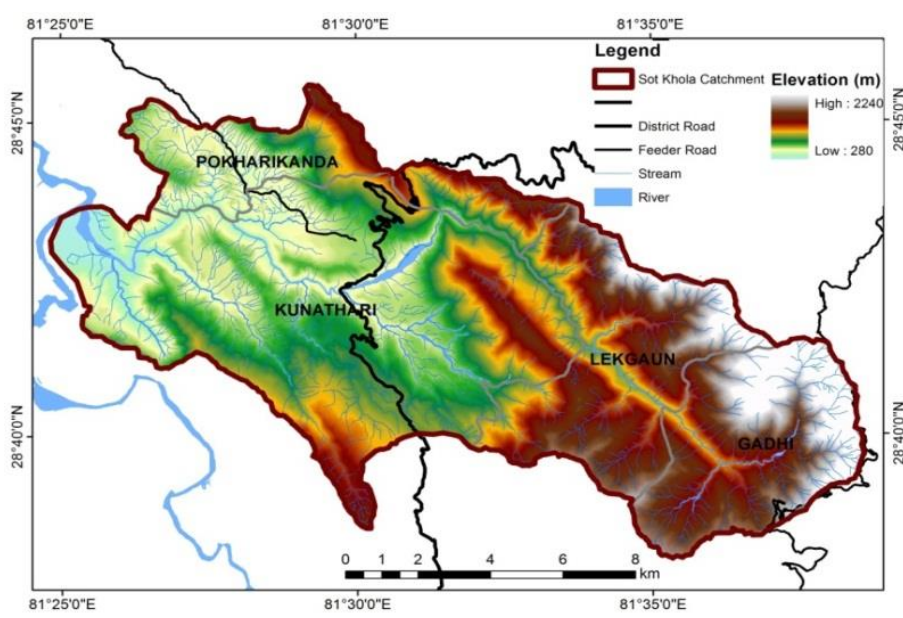
meter in the Mahabharata Range (Figure 2). Its location is $9 \mathrm{~km}$ far north from District headquarter. Its area is 28 square $\mathrm{km}$. Population size is 3369 out of which main castes are Magar (37.7 percent), Brahmin (30.6 percent), Cheetri (17.1 percent), Sunwar (5.7 percent) and others (22.6 percent). Others include Kami, Sarki, Thakuri, Gurung, Damai, Sherpa, etc (VDC, 2015). b) Lekhgaon VDC lies 198 meter (Tata pani) to 2369 meter (Matela gurase) altitude (Figure 2). It spreads $110 \mathrm{~km}$ length and $30 \mathrm{~km}$ breadth of 2451 square $\mathrm{km}$ (249016 hectare). Hill dominates with 84 percent. The remaining 16 percent is valley. Population size is 3999 (651 households) (DDC, 2015). c) Kunathari is catchment area lying between 600 meter and 1200 meter (Figure 2). It is $20 \mathrm{~km}$ far from district headquarter). Population size is 3413 (CBS, 1991) and (DDC, 2015).

Paddy is a major cereal crop in all over the country, Nepal from low altitude (Terai district-Birgunj, Siraha, Dhangadhi etc.) to high altitude (Mountain Districts -Manag and Mustang etc.). Despite its low productivity and poor ecological friendliness, farmers prefer paddy production for their livelihood. Thus, its production relates with Nepalese family's paddy feeding habits and livelihood. CBS (2019) shows 9 percent paddy production with 5.6 million tons in 2018. Its production per hectare is 3.76. Its contribution is 1 percent in economic growth rate of Nepal and significant in 26 percent GDP contribution of agriculture and forestry. Therefore, paddy is a source of livelihood and economic growth.

The study district, Surkhet is one of paddy producing districts, despite its high-altitude location. In 2018, its paddy production per annum was 33300 tones. In total national paddy production, its contribution and share are still nominal with lower productivity with reference to 3.76 tons per hectare.

Paddy production in Surkhet is stagnant due to climatic threats and risks, along with higher rate of land fragmentation, excessive use of traditional knowledge and technology, ignorance to soil quality and ecological factors, no irrigation facility, shortage of fertilizers and lack of skilled manpower. Despite a beautiful policy objectives and priority on paddy production growth and productivity per hectare in the long-term plan (Agricultural Perspective Plan), the plan was not implemented properly (MoAD, 2015). Therefore, paddy has a production risk due to climate change and its uncertainties and risks. 


\section{Results and Discussion}

\subsection{Climatic Change and Climate change induced hazards and Vulnerability}

IPCC (2001), UNDP(2018) and Ministry of Science and Technology(MoST) (2018) and Bista (2017) have empirically and theoretically found climate variation and hazards and vulnerability Figure 3: Average Rainfall in Surkhet District

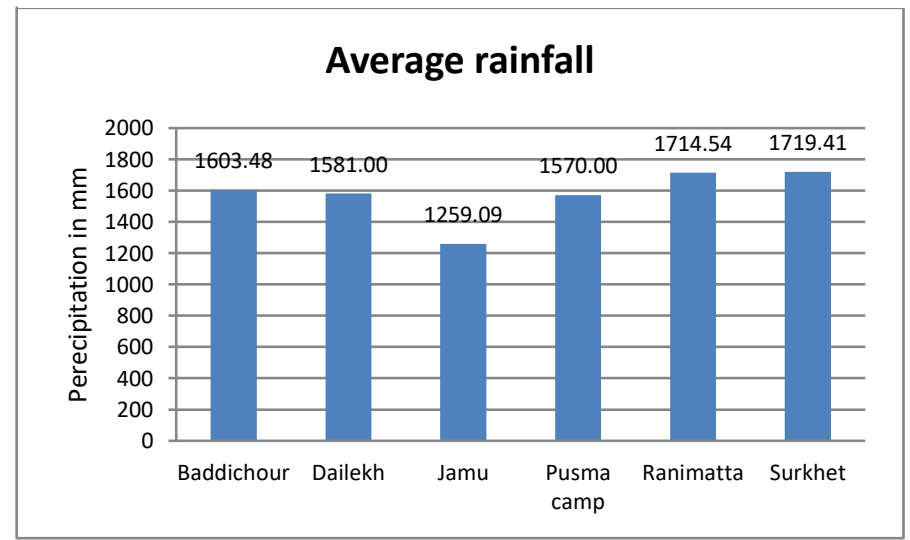
outcomes not only in Kathmandu but also all over the country. Therefore, western mountainous districts including Surkhet has climate variation and vulnerability outcomes. Therefore, Surkhet has climate variation hazards and risk.

Climatic variables including temperature and rainfall variation in Surkhet District are noticed by the department of hydrology and metrology and experienced by local residents in Focused Group Discussion (FGD) and Key Information Informant (KII)

(2015). Over 30 years, temperature trend is positive with temperature growth rate per annum from Figure 5: Seasonal Precipitation of Study Area

\section{Seasonal precipitation}

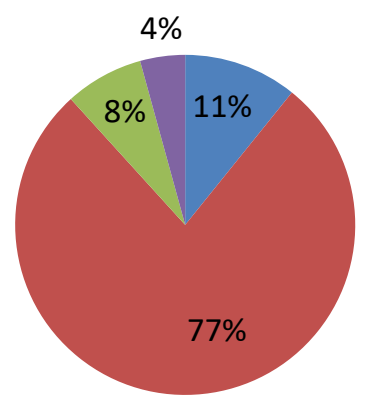

- Premonsoon

Monsoon

Post Monsoon

- Winter $0.5^{\circ} \mathrm{c}$ to $1^{0} \mathrm{c}$. It is continuous. Rainfall is 1719 mili meters (Figure 3). It starts from June July and August. Its coverage is approximately 88 percent in monsoon season (Figure 5). Its starting month is quite earlier or quite later. Thus, rainfall pattern and trend are varied. Similarly, the respondents had its bitter experience. In case of temperature rising, mosquito was measurement of temperature rising. In Gadhi, there was no mosquito at this higher altitude before 15 years. However, mosquito is available and can fly not at ground level but also at third and fourth floor because mosquito survive only in higher temperature. It indicates mosquito shifted to high hills from plain lands. It is found in Lekhagaon and Kunathari. Similarly, rainfall was a week long and widely covered before 15 years

Figure 4: Monthly Rainfall Pattern in Study Area

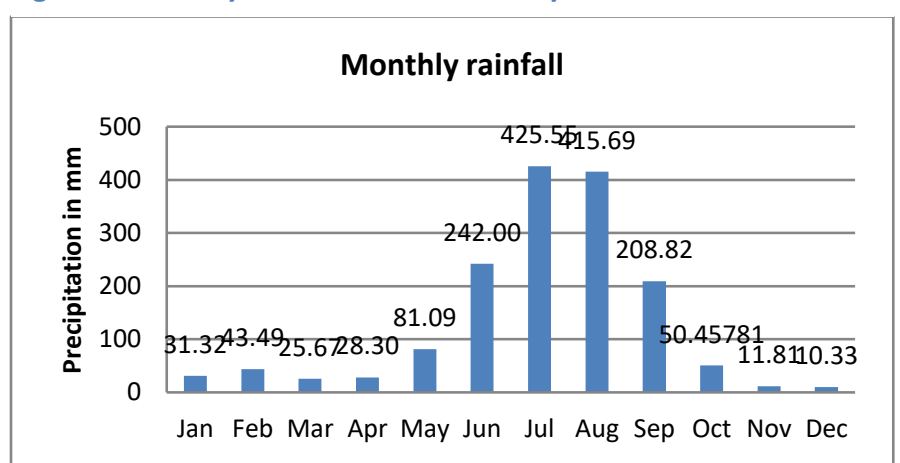
ago. At present, its duration is only two days. Its distribution is erratic and intense more than 15 years ago. Such pattern of raining has not been a backbone of irrigation, except flood and landslides. Therefore, Surkhet is climatic sensitive district.

As a result of climatic variation, the flood of Sot Khola and landslides of Sot Khola watershed catchment areas in 2014 happened in Surkhet District. The flood was unexpectedly destructive roaring to its banks: agricultural land and crops, road, clean drinking water, bridge and building. Rainfall induced 


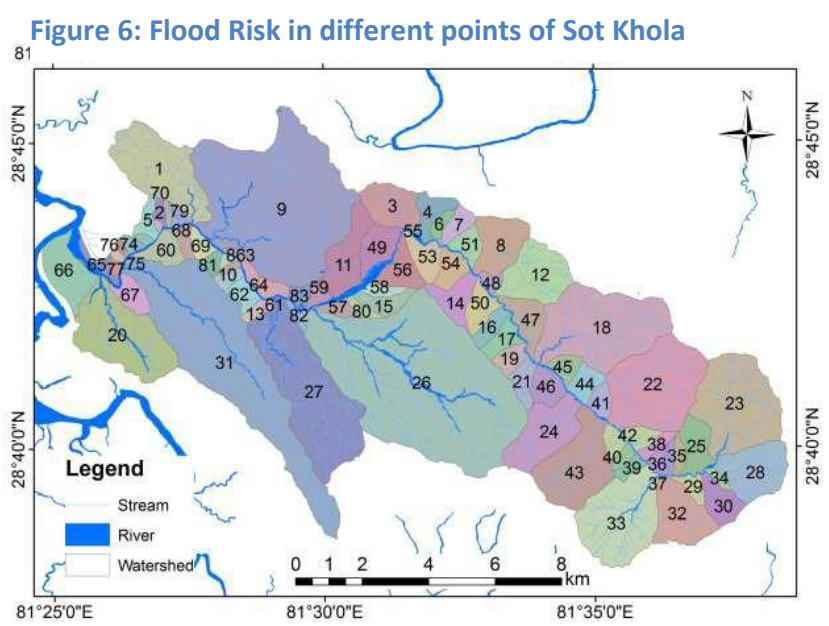

landslides too in its catchment areas. Flood risk analysis provides its 83 small rivulets having 86 points flood disaster risk (Figure 6). However, there were not human settlements in the corridor of the river, except fertile land. As such, detailed flood risk analysis of each microwatershed in not warranted.

Another result was landslide in Surkhet District (Figure 7). In 2014, there was simultaneous extreme climatic event, landslides. The field observation and FGDs identified 29 landslides locations out of which there were highly vulnerable locations such as 11 locations in Lekhagaon, 10 locations of Gadhi and 8 locations in Kuathari. Dynamics analysis of landslides

Figure 7: Landslides patch up areas of Sot Khola watershed Catchment Areas

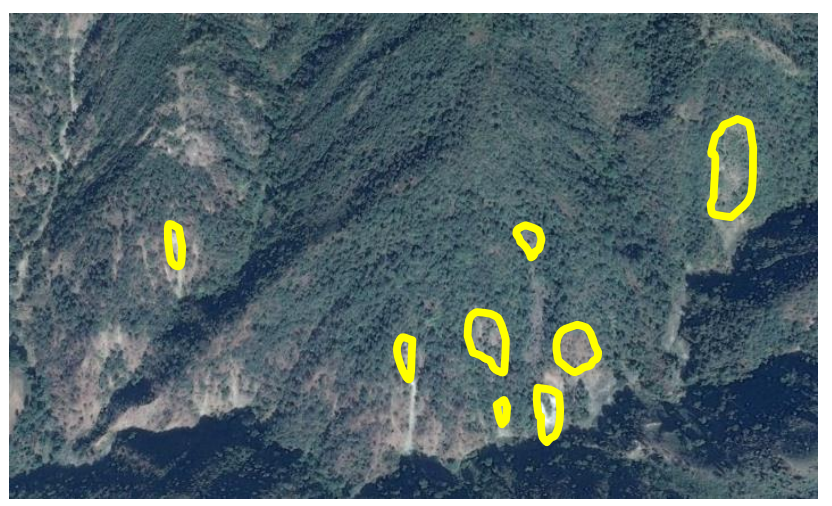
shows Lekhagaon is more vulnerable VDC than Gadhi and then Kunathari. Its

The Satellite images and aerial photographs study reveals that the area has significant number of landslide scars which reveals that the area encountered many landslides in past (www.google.mp/Sot Khola water basin)

\subsection{Effects of Climate change and Climate Change Induced hazards in Paddy Production}

Paddy production is very sensitive and exposure to climatic variables (temperature and rainfall) and to water and land related disasters (flood and landslides). At terrace land, there is higher sensitivity to landslides and at plain land, there is higher sensitive to flood. Therefore, paddy production at terrace land and plain land has higher production risk. Its example is natural disasters in Sot Khola watershed and catchment areas in 2014.

In the study areas, multiple natural hazards have negative output and negative outcomes in terms of economic loss. In 2014, flood was wildly and extremely powerful to curb the sides of rivers at 86 points and dump sediments (mud, stones, leaves, wood, irons, steels, trees etc.) in the fertile land located at low land. It cleaned the existed valuable physical infrastructure (road, bridge, houses and land). Its outcomes were the growth of poverty and inequality led extreme vulnerability through the loss of paddy and its productivity. Thus, food has negatively related with the flood. Landslides were 29 locations. It had also similar result of the flood. Its outputs are as follows.

4.2.1. Bank cutting and sedimentation are outcomes of the wild flood of Sot Khola watershed in 2014. In the stream, there were extreme bank cutting in four locations: lower Ratomate, Bodichure, Finikada and Raksheni through which the stream entered in the range from 30 meter to 50 meters more than before in the fertile land. Its length was from 1000 meter to 5000 meters. By location, lower Ratomate had bank cutting of 7.39 bigha (1.18 hectare) followed by bodichure with 44.29 Bigha (7.11 hectare) bank cutting, Finikada with 18.45 Bigha (2.96 hectare) and Raksheni with 8.85 Bigha (1.42 hectare). In total, there was sediment and bank cutting of fertile land of 78.85 Bigha 
(12.6 hectare). Thus, there was a loss of 78.85 Bigha (12.6 hectare) fertile lands in the watershed areas. Its outcome was loss of fertile land and livelihood security.

4.2.2. Soil erosion and sedimentation are another outcome of landslide disaster in Sot Khola watershed catchment areas: Gadhi, Lekhagaon and Kunathari during erratic and heavy rainfalls because the catchment areas are at hill areas having terrace and steep lands. Landslide events happened disastrously in 11 locations of Lekhagaon VDC, 10 locations of Gadhi and 8 locations of Kunathari. Almost landslide patch up areas lied in the range from 100 meter to 1000-meter length and from 50 meter to 200 meter wide. Since landslides induce soil erosion and sedimentation at bottom level, almost landslides patches had heavy sedimentation and running soil erosion. Its result was loss of fertile terrace land and downward flowing houses. Its outcome was desertification, displacement and tragic and heavy economic losses. Thus, disaster challenges human livelihood, human behavior and survival.

\subsection{Farmer's Adaptation Options, Adaptation Activity and Behavior in Paddy Production}

It is no doubt that different peoples have different adaptation capacity, activity and behavior to minimize the negative consequences of climate hazards. If adaptation capacity, activity and behavior is excessive, their exposure and sensitivity will be lower. However, it is reverse. The higher exposure and higher sensitivity of the people will induce extreme vulnerable. Therefore, adaptation capacity, activity and behavior are significant to all climatic hazards.

There are different adaptation options. UNFCCC (2007) mentions a) Knowledge and assessment, b) Early warning system, c) Wall construction, d) Removing sedimentation and reclaim land, e) Irrigation facility, f) Using water efficient crop seed and g) Crop insurance (UNFCCC, 2007). Similarly, farmers have also indigenous knowledge, skill, activity and behavior.

In paddy production, almost small farmers employ their indigenous knowledge, skill, activity and behavior in Nepal. In Surkhet, there were similar practices in paddy production because these are simple, easy, know-how and cost-effective methods.

\subsubsection{Farmer's Adaptation Activity and Behavior in Paddy Production}

Out of above seven adaptation options, there were the practice of wall construction, maintenance to house and removing sedimentation from agriculture land in the field survey and observation. Figure 8 shows three adaptation activity: house maintenance, removing residuals from agriculture land and wall construction, along with seed switch on and irrigation.

- House maintenance is done by farmers themselves by using local materials: mud, stone and wood by using indigenous knowledge, skills and technique. In these areas, farmers have constructed drainage system to stop landslides and soil erosion. It is for safe not for themselves and also for the family. Further, it is for security and safe of materials.

- Wall is constructed by farmer to control flood and preventing soil erosion and flooding residual (stone, leaf, iron, etc.). Farmers use traditionally bamboo and tree at the individual plot. Its scale is small. At collective level, it is adopted for the collective interest and benefit.

- Removing sedimentation from agriculture land is initiated by the farmers to reclaim the agriculture land for agricultural activities. In flood and landslides, there was a great practice.

- Seed is changed to minimize the flood's risk and climate shock. Farmers have used seed adjusting flooding and climate shock.

- Irrigation is another effective adaptation behavior. Its irrigation canal is able to divert flood at some extent and to minimize its risk and damage. 
In Figure 8, almost all household who are farmers having conservative and traditional have three adaptation options, activity and behaviors: house maintenance, removing residuals from agriculture land and wall construction before and after climatic hazards. Adaptation activity and behaviors in the study area was determined by the level of climate hazards and household adaptation capacity. In Gadhi VDC, almost households employed mixed three options for adaptation activity and behavior because the village had risk of flood and landslides. Each adaptation option received 33.3 percent weightage preference for minimizing the outcomes of the flood and of landslides not only to house building and also to fertile land (Figure 8). They applied their indigenous knowledge, skill and technique. To save two story small stone house, they constructed drainage top, side and bottom house so that rain water could get its passage and way out. Wall and roof of house were maintained to stop water leakage, along with clearance of all dust, waste and other materials in the way and drainage. Once upon fertile land is sedimented. Its degradation starts. Therefore, farmers tried to clean sedimentation as well as possible and planted trees and bamboos to stop top fertile soil erosion by using recycle and reallocate method. In the bank of Sot Khola watershed, the farmer constructed bamboo wall to protect the fertile land from soil erosion and flooding unwanted residuals (stone, leaf, iron, etc.) at lower cost in the watershed areas. There were approximately 60 places. At some extent, farmers were satisfied on the effective of low cost indigenous such adaptation activity and behavior to minimize production risk of paddy due to landslides and floods.

Differently, almost all farmers $(100 \%)$ had adaptive behavior of removing residuals from agricultural land for land preparation for next paddy cultivation in Lekhagaon because there were more landslide events in Lekhagaon (11) than Gadhi (10) and Kunathari (8) (Figure 8). Meanwhile almost all farmers (100\%) preferred wall construction adaptive behavior in Kunathari for protecting agricultural land from the flood because Kunathari had heavy bank cutting and sedimentation in many places of the bank of Sot Khola watershed (Figure 8).

In addition, negligible household employed to change crop, seed and irrigation.

Figure 8: Adaptation Option and Activity of Farmers

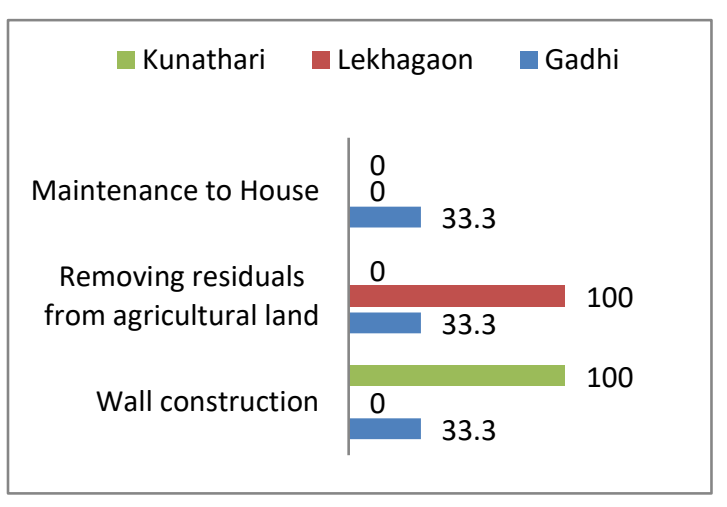

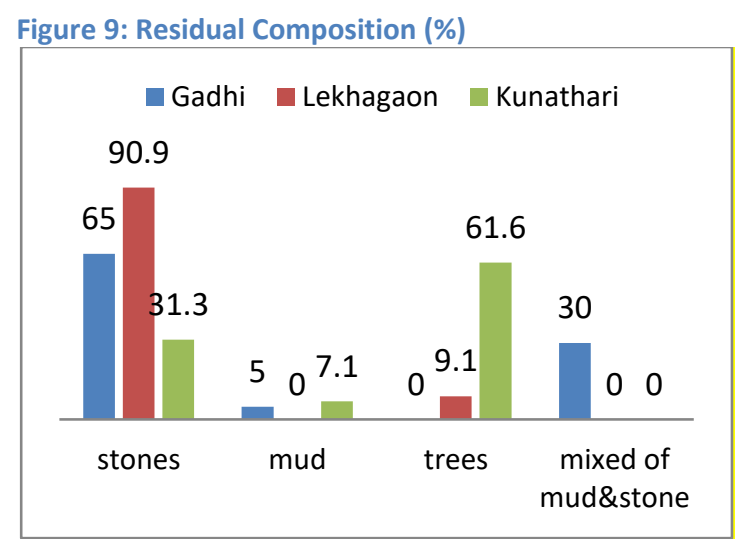

Source: Field Survey, 2015

Figure 9 shows residual deposited and carried out by flood and landslide. The residual that is immensely huge deposited in the agricultural land is heterogenous including stone, mud and tree. Its composition is dominated by small stones residual as follows 90.9 percent in Lekhagaon, 65 percent in Gadhi and 31.3 percent in Kunathari. Similarly, tree residual was 61.6 percent in Kunathari and 9.1 percent in Lekhagaon and mud was 7.1 percent in Kunathari and 5 percent in Gadhi. Small stones and trees sedimentation degraded top fertile soil. Its outcome would be lower productivity and the growth of livelihood insecurity. 


\subsubsection{Effects of Adaptation Behavior of Farmer on Paddy Production}

\subsubsection{Estimates of Adaptation shocks}

In $\mathrm{CD}$ production econometric model, total paddy income $\left(\mathrm{Y}_{\mathrm{r}}\right)$ is dependent variable and labor $(\mathrm{L})$, land $\left(\mathrm{L}_{\mathrm{a}}\right)$, fertilizer $(\mathrm{F})$, Seed $(\mathrm{S})$, two adaptation activities $\left(\mathrm{D}_{1}\right)$ having $1=$ wall construction, $0=$ others (seed change) and Areas dummies $-\mathrm{D}_{2}$ having $1=$ Gadhi and $0=$ others, $\mathrm{D}_{3}$ having $1=$ Lekhagaon and $0=$ others and $\mathrm{D}_{4}$ having $1=$ Kunathari and $0=$ others are independent variables. The relationship between total paddy income, adaptive shocks and disaster-prone areas was a curiosity. In this study, we had focused two questions:

- What would adaptive shocks contribution to total paddy income?

- Which one adaptive shock was effective in paddy production areas?

Based on household survey data, we tried to trap the effects of adaptation shocks to minimize climate disasters after the estimations of coefficients of above these questions such as unknown $\beta 5$ and $\beta 6$ coefficient of adaptive shocks and $\beta 7$ and $\beta 8$ coefficients of disaster-prone areas. From this CD semi log econometric model, these unknown coefficients were estimated and interpreted.

\subsubsection{Result: Descriptive Statistics}

Table 1 presents mean and standard deviation of key variables in multiple semi log regression model estimation. In column 1, there are 10 variables in which household vulnerability in terms of income lost in log form (ln paddy revenue) is dependent variable and labor $(\mathrm{L})$, land $\left(\mathrm{L}_{\mathrm{a}}\right)$, fertilizer $(\mathrm{F})$, Seed(S) $\mathrm{D}_{0}$ (climate shock), $\mathrm{D}_{1}$ (adaptation shock), $\mathrm{D}_{2}$ (Gadhi), $\mathrm{D}_{3}$ (Lekhagaon) and $\mathrm{D}_{4}$ (Kunathari) are independent variables. Standard deviations of these variables from mean are no so far significant. The mean of these variables represents properly household data collected from primary sources.

Table 1: Mean and Standard Deviations: Semi Log Regression Model
\begin{tabular}{llc}
\hline & \\
\hline Variables & Mean (Std. Deviation) \\
\hline Revenue generated from paddy & $5.11(4.82)$ \\
Land (ln area paddy) & $3.8(5.30)$ \\
Labor (In no Labor) & $1.21(1.00)$ \\
Seed (In seed) & $1.35(1.05)$ \\
Fertilizer (ln Ferti) & $0.41(1.25)$ \\
Occurrence of climate shock (1=Flooc & $0.94(.22)$ \\
0=others(landslides) & \\
Adaptive Shock 1: Wall Construction & $0.58(.49)$ \\
(1=Yes, 0=others (removing & \\
sedimentation) & \\
$\mathrm{D}_{2}$ (Gadhi VDC) & $0.13(.34)$ \\
$\mathrm{D}_{3}$ (Lekhagaon) & $0.22(.42)$ \\
$\mathrm{D}_{4}$ (Kunathari) & $0.63(.48)$
\end{tabular}

\subsubsection{Results: Empirical Estimation}

Table 2 provides the results of semi log regression model of dependent variable in log form (lnpaddy revenue) and 11 independent variables including labor $(\operatorname{lnL})$, land $\left(\ln L_{a}\right)$, fertilizer $(\operatorname{lnF}), \operatorname{Seed}(\ln S)$ $\mathrm{D}_{0}$ (climate shock), $\mathrm{D}_{1}$ (climate adaptation), $\mathrm{D}_{2}$ (Gadhi VDC) and $\mathrm{D}_{3}$ (Lekhagaon VDC) are independent variables There are nine parameters: $\beta, \beta_{1}, \beta_{2}, \beta_{3}, \beta_{4}, \beta_{5}, \beta_{6}, \beta_{7}$, and $\beta_{8}$. In parenthesis 
C-D Production Function

ln $\mathrm{Y}_{\mathrm{a}}=3.59-1.1 \operatorname{lnL}-0.17 \ln \mathrm{L}_{\mathrm{ag}}-0.12 \operatorname{lnf}+3.57 \operatorname{lns}-0.97 \mathrm{D}_{1}$ (climate shock)-3.6 $\mathrm{D}_{2}$ (Gadhi)-2.89 $\mathrm{D}_{3}$ (lekhagaon)

Table 2: Results of Semi Log CD Production Econometric Model

\begin{tabular}{|c|c|c|c|c|c|c|c|c|c|c|}
\hline Regressor & 1 & 2 & 3 & 4 & 5 & 6 & 7 & 8 & 9 & 10 \\
\hline Constant & $\begin{array}{r}3.59 \\
(1.56)\end{array}$ & & & & & & & & & \\
\hline $\begin{array}{l}\text { Proportion of labor in } \\
\text { ag production }(\ln L)\end{array}$ & & $\begin{array}{r}-1.1 \\
(2.57)\end{array}$ & & & & & & & & \\
\hline $\begin{array}{l}\text { Proportion of land } \\
\text { used in ag production } \\
\text { (ln area of paddy) }\end{array}$ & & & $\begin{array}{l}-.17 \\
(.075)\end{array}$ & & & & & & & \\
\hline $\begin{array}{l}\text { Proportion of } \\
\text { fertilizer used in ag } \\
\text { production }(\ln F)\end{array}$ & & & & $\begin{array}{l}-.12 \\
(.43)\end{array}$ & & & & & & \\
\hline $\begin{array}{l}\text { Proportion of seed } \\
\text { agricultural } \\
\text { production(Ins) }\end{array}$ & & & & & $\begin{array}{r}3.57 \\
(2.44)\end{array}$ & & & & & \\
\hline $\begin{array}{l}\text { Climate shock (yes=1, } \\
0=0 \text { thers) }\end{array}$ & & & & & & $\begin{array}{r}-.97 \\
(1.63)\end{array}$ & & & & \\
\hline $\begin{array}{l}D_{1} \text { Adapt shock-1: wall } \\
\text { construction } \quad \text { (yes=1, } \\
\text { others=0) }\end{array}$ & & & & & & & $\begin{array}{c}1.41 \\
(.729)\end{array}$ & & & \\
\hline $\begin{array}{l}\text { D }(\text { Gadhi)(yes=1, } \\
\text { 0=others Kunathari) }\end{array}$ & & & & & & & & $\begin{array}{l}-3.6 \\
(1.52)\end{array}$ & & \\
\hline $\begin{array}{ll}\mathrm{D}_{3} & \text { (Lekhagaon) } \\
\text { (yes=1, } & \text { O=others } \\
\text { Kunathari) } & \\
\end{array}$ & & & & & & & & & $\begin{array}{l}-2.89 \\
(0.88)\end{array}$ & \\
\hline
\end{tabular}

F-value $=10.81$, at 5 percent, $\mathrm{df}=8,118, \mathrm{R}^{2}=0.65$

\subsubsection{Discussion}

Above results of semi log econometric model provide sufficient and necessary evidence on coefficient of independent variables on household vulnerability (income loss of household). Estimation of coefficient explains how much the change of paddy revenue is affected by the change of adaptive capacity, geography and climatic shock (the flood). In the result of the model, $\mathrm{R}^{2}$ value is 0.65 . It means the independent variables are exploratory at 65 percent. There is still 35 percent error term which includes the different unobserved variables. It indicates higher goodness to fit. In addition, F-value shows its significant level.

Paddy production in agriculture is main cereal crop in Sot Khola watershed area. Since the threat of climate hazards is as production risk and instability, revenue loss in paddy production has induced vulnerability to farmers household. Therefore, semi log model of C-D production has been employed to understand the impact of climate shock, adaptation behavior of household and status and difference in areas (Gadhi, Lekhagaon and Kunathari). In this way, above independent variables have either positive or negative relationships with paddy revenue in those three VDCs: Gadhi, Lekhagaon and Kunathari. Let's present one by one independent variables influencing to paddy production.

Labor is active input of paddy production function. In rural areas, skill of labor is inferior having zero marginal productivity because household crowds out using family members (old age, women and children) in paddy production, despite unskilled labor. No of labor employed in paddy production is significant to the paddy revenue to produce at $1 \%$ level. Assuming other variables are constant but the proportion of labor input increases by 1 unit, 
the paddy production decreases by $1.1 \mathrm{Rs}$ of paddy revenue. It indicates zero marginal productivity.

- Use of land in paddy production is major determinant. If it is fertile, its contribution will be valuable in terms of productivity. If not, its contribution will be negative. In rural hilly areas, land is generally found the dominance of terrace land (less productive land and no access to irrigation). In simple, lower paddy productivity and production can be observed. Area of land employed in paddy production is significant to the paddy revenue to produce at $1 \%$ level. Assuming other variables are constant but the land input increases by 1 Katha, the paddy production revenue decreases by Rs. 0.17(0.0017 USD). Surprisingly, land and paddy production have not positive relationship. There may be inferior fertility not favoring paddy production.

- Fertilizer is major source of paddy crop nutrient. Chemical fertilizer is considered as good source relatively to organic fertilizer. There is used livestock manure as organic fertilizer because of unavailability of chemical fertilizer in almost places of watershed. In addition, farmers have not knowledge about how to make perfect organic fertilizer from livestock manure. Therefore, there is a suspicious about fertilizer's contribution. Fertilizer in paddy production is significant to the paddy revenue to produce at $1 \%$ level. Assuming other variables are constant but the land input increases by $1 \mathrm{Kg}$, the paddy production revenue decreases by Rs. 0.12(0.0012 USD). Interestingly, fertilizer has not contributed to increase paddy productivity and production and further paddy revenue growth.

- Seed is very important to get higher productivity and production of paddy. Despite negative situation, the improved seed distributed by District Agricultural Office (DAO) has positive contribution. Paddy seed is significant to the paddy revenue to produce at $1 \%$ level. Assuming other variables are constant but paddy seed input increases by 1 unit, the paddy production revenue increases by Rs. 3.57(0.0357 USD). In the assessment of inputs in paddy production, the improved seed has played a positive role to increase paddy productivity and production.

- Climate shock is captured in Dummy variable $\left(\mathrm{D}_{0}\right)$ in which $1=$ flood and $0=$ landslides and other. Climate change induced shock has affected to fertile land through bank cutting, damage to crops, deposition of sedimentation in terrace land, destruction of irrigation system in the watershed areas. This dummy is significant to the paddy revenue. Let's assume other variables are constant. When there is the occurrence of flood, the paddy revenue will be Rs 2.62 (0.0262USD). In case of landslides and other, the paddy revenue will be Rs. 3.59(0.0359 USD). Thus, both shocks have difference of Rs. 0.97(0.0097 USD) in paddy production. Both have negative impact on paddy production and productivity.

- Agriculture is main occupation of farmers and main source of household income, food and employment in the watershed areas. They have traditional and modern knowledge to reduce negative impact of climate shock on paddy production for maintaining paddy revenue. They have used such knowledge as adaptation behavior and activity in terms of wall construction, seed change and removing sedimentation. To capture such behavior and activity, Dummy variable $\left(D_{1}\right)$ is used 1 for wall construction and 0 for other (seed change and removing sedimentation). Let's assume other variables are constant but wall construction is constructed to prevent the flood, paddy revenue will increase by Rs.1.41 and then Rs 5. If not, paddy revenue will increase by 3.59 Rs (0.0359 USD). There is difference between two adaptation options that is Rs. 1.41(0.0141 USD).

- Ecological and altitudinal factors influence on paddy production and productivity. In the watershed areas, there are two types of ecological and altitudinal that is the upstream (Gadhi and Lekhagaon) and the downstream (Kunathari). Assuming other variable are constant, the 
revenue from paddy production in the upstream (Gadhi and Lekhagaon) are significantly lower than the downstream (Kunathari) at the $1 \%$ level because area used paddy production in the upstream (Gadhi and Lekhagaon) are at higher altitude and terrace land under higher threat of climate change and climate change induced but land in the downstream (Kunathari) is at lower altitude and plane land having irrigation facility.

In conclusion, household vulnerability is influenced by family member, landholding, knowledge, experience and agricultural income. These variables have significant impacts.

\section{Conclusion}

Paddy production is main cereal crop all over the country. This crop is in risk from changing climatic variables and disasters (flood and landslide). Generally, flooding, bank cutting and landslides which were climatic disastrous to paddy production and then the local people (farmers) of the Sotkhola catchment hilly areas damaged at huge but it was minimized by the adaptive capacity and behavior of the local people. To control flood and landslide, they first preferred wall construction and then changing seeds and developing irrigation system. During such event, almost all preferred in the safe place and regular updated information. Thus, the growth of complicated and multiple climate hazards is spreader of natural hazards and risk extensively and intensively to paddy production as well as agriculture sector. However, farmers employ their own indigenous adaptive knowledge, skill, capacity and behavior at some extent neutralization of climate hazards and negative outcomes. Despite these adaptation options, activity and behaviors, paddy production is not resilient to maintain its productivity and production and farmer's annual revenue. Therefore, national and local level development policy and program should be climate resilient to reduce the climatic risk in paddy production food security, livelihood and welfare.

\section{Reference}

Acharya, S. P. and Bhatta, G.R. (2013). The impact of climate change on agricultural growth in Nepal. Working paper series, 15(201).

Adger, W. N (2006). Vulnerability. Global Environmental Change, 16 (3), 268-281.

Bhandari, G. (2013). Effect of precipitation and temperature variation on the yield of major cereals in Dedeldhura Districts of Far Western Development Region, Nepal. International Journal of Plant, Animal and Environmental Sciences, 3(1), Jan- Mar.

Central Bureau of Statistics (CBS). (2011). Population census. Kathmandu: CBS

Chalise, S.R and Khanal, N.R. (2002) 'Recent extreme weather events in the Nepal Himalayas'. In Snorrason, A.; Finnsdottir, H.P.; Moss, M.E. (eds) The extremes of the extremes: Extraordinary floods, Publication 271, 141-146. Reykjavik (Iceland): IAHS

Dahal, R.K., Hasegawa, S., Nonomura, A., Yamanaka, M., Dhakal, S., and Paudyal, P. (2008). Predictive modeling of rainfall-induced landslide hazard in the Lesser Himalaya of Nepal based on weights-ofevidence. Geomorphology, 102, 496-510.

DDC (District Development Committee) (2015). District Profile. Surkhet: DDC 
Elisch, J. (2008). Climate change: Financing global forests. London: The Stationary Office Limited.

Fussel, H.M. (2007). Vulnerability: A generally applicable conceptual framework for climate change research. Global Environmental Change, 17, 155-167.

Füssel, H-M. and Klein, R.J. (2003). Vulnerability and adaptation assessments to climate change: An evolution of conceptual thinking' Paper presented at UNDP Expert Group Meeting Integrating disaster reduction and adaptation to climate change, Havana, Cuba, 17-19 June 2002.

IPCC (2001). Climate change 2001: Impacts, adaptation and vulnerability. Summary for policymakers, Cambridge: Cambridge University Press.

Karki M. B, Shrestha A.B., Winiger M. (2011). Enhancing knowledge management and adaptation capacity for integrated management of water resources in the Indus River Basin. Mountain Research and Development 31(3):242-251.

Karn, P.K. (2014). The impact of climate change on paddy production in Nepal. SANDEE Working Paper No. 85-14. Kathmandu: SANDEE

Malla, G. (2008). Climate change and impact on Nepalese agriculture. Journal of Agriculture and Environment, 9(5).

Ministry of Agriculture Development (MoAD) (2015) Agriculture Development Strategy. Kathmandu: MoAD

Ministry of Finance (MoF) (2018). Economic Survey. Kathmandu: MoF

Mool, PK; Bajracharya, SR; Joshi, SP (2001a) Inventory of glaciers, glacial lakes, and glacial lake outburst floods: Monitoring and early warning systems in the Hindu Kush-Himalayan region - Nepal. Kathmandu: ICIMOD

Nicholls, R.J., Leatherman, S.P, Dennis, K.C. and Volonte, C. R. (1995). Impacts and responses to sea level rise: Qualitative and quantitative assessments. Journal of Costal Research, 14, 26-43.

OECD (2009) Managing Risk in Agriculture: A Holistic Approach. France: OECD http://www.oecd.org/publications/managing-risk-in-agriculture-9789264075313-en.htm

Pant, K.P. (2011). Economics of climate change for smallholder farmers in Nepal: A Review paper, The Journal of Agricultural and Environment, 12(5).

Pant, K.P. (2012). Climate change and food security in Nepal. The Journal of Agricultural and Environment, 13(5).

Sterns, N. (2006). The Economics of Climate Change. London: H.M Treasury.

United Nations Framework Conventions on Climate Change (UNFCCC). (2002a). Climate change: Impacts, vulnerabilities and adaptation in Developing countries. Bonn: UNFCCC Secretariat.

United Nations Framework Conventions on Climate Change (UNFCCC). (2007). Climate change: Impacts, vulnerabilities and adaptation in Developing countries. Bonn: UNFCCC Secretariat. 